\title{
ANALISIS KARAKTERISTIK GAYA BELAJAR VAK(VISUAL, AUDITORIAL, KINESTETIK)MAHASISWA PENDIDIKAN INFORMATIKA ANGKATAN 2014
}

\author{
Ariesta Kartika Sari \\ Universitas Trunojoyo Madura \\ Bangkalan, Indonesia \\ ariestakartika@ymail.com
}

\begin{abstract}
Abstrak
Salah satu karakteristik belajar yang berkaitan dengan menyerap, mengolah, dan menyampaikan informasi tersebut adalah gaya belajar peserta didik. Gaya belajar merupakan modalitas belajar yang sangat penting. Informasi terkait karakteristik gaya belajar mahasiswa yang akan diajari, sangat penting bagi dosen untuk meningkatkan kualitas pembelajarannya.Mahasiswa juga akan lebih mudah memotivasi dirinya dalam pembelajaran. Penelitian ini merupakan penelitian non-eksperimen, yaitu tergolong pada penelitian deskriptif kualitatif. Subjek penelitian ini adalah seluruh mahasiswa program studi pendidikan informatika yang berasal dari angkatan 2014. Instrumen yang digunakan dalam penelitian ini berupa angket/kuesioner yang akan diisi oleh subjek penelitian. Angket gaya belajar ini diisi oleh sebanyak 115 subjek penelitian yang berasal dari mahasiswa Pendidikan Informatika Angkatan 2014. Hasil analisis gaya belajar terhadap Mahasiswa Kelas A didominasi oleh gaya belajar Visual (53\%), Kelas B didominasi gaya belajar Auditorial (35\%), dan Kelas C didominasi gaya belajar didominasi Visual (29\%). Secara keseluruhan, kecenderungan gaya belajar Mahasiswa Angkatan 2014 Prodi Pendidikan Informatika didominasi oleh tipe gaya belajar Visual sebesar 33\%. Contoh karakteristik pembelajaran yang cocok untuk mahasiswa visual adalah memotivasi mahasiswa untuk menggambarkan informasi, dengan membuat diagram, simbol dan gambar berwarna dalam catatan mahasiswa Visual.
\end{abstract}

Kata Kunci: Gaya Belajar, Visual, Auditorial, Kinestetik. 


\begin{abstract}
One of the characteristics of the study relating to absorb, process, and transmit the information is learning styles of learners. Learning styles is a very important learning modality. Information related to the characteristics of student's learning styles that will be taught, is important for lecturersto improve the quality of learning. Students will also be easier to motivate himself in learning. This research isa non-experimental study, which belong to the qualitative descriptive research. The subjects were all students of informatics education study programs originating from the class of 2014. The instrument used in this research was a questionnaireto be filled by research subjects which completed by 115 subjects. The results of the analysis of the student's learning style Class $A$ is dominated by visual learning style (53\%), Class B is dominated by auditory learning style (35\%), and Class $C$ is dominated by Visual learning style (29\%). Overall, the tendencyof student learning style the 2014 of Informatics Education study programs dominated by the type of Visual learning style by 33\%. Examples of characteristics suitable for Visual learning style is to motivate students to visually describe the information, to make diagrams, symbols and color images in Visual student records.
\end{abstract}

Keywords: Learning styles, Visual, Auditory, Kinesthetic. 


\section{PENDAHULUAN}

Setiap anak yang dilahirkan memiliki karakteristik kemampuan otak yang berbeda-beda dalam menyerap, mengolah, dan menyampaikan informasi. Belajar merupakan aktivitas mental yang melibatkan kemampuan otak dalam menyerap, mengolah, dan menyampaikan informasi. Tentu saja bahwa belajar bukanlah hanya kegiatan menghafal saja. Banyak hal yang akan hilang (bersifat tidak permanen) dalam beberapa jam. Untuk mengingat apa yang telah diajarkan, peserta didik harus mengolah informasi tersebut dan memahaminya.

Sebagaimana kita ketahui bahwa kita memiliki otak dengan karakteristik unik antara otak kiri dan otak kanan manusia. Otak kanan memiliki karakteristik Long term memory sedangkan belahan otak kiri tergolong dalam Sort term memory. Di dalam bukunya yang berjudul Revolusi Belajar untuk Anak, Bob Samples (2002) mengungkapkan gagasan terkait: (a) fungsi otak-pikiran sebagai sistem terbuka; (b) modalitas, kecerdasan, gaya belajar, dan kreativitas dalam belajar, serta cara-cara pengembangannya; (c) pemanfaatan musik, suara, relaksasi, gambar, humor, dan mimpi untuk membangun suasana bermain dan belajar secara efektif serta mengasyikkan dengan anak-anak, tanpa mengurangi hakikat pembelajaran; serta (d) aktivitas, kiat, dan saran yang mudah dilakukan untuk mengembangkan kemampuan belajar dan mengakses informasi melalui seluruh modalitas belajar yang kita miliki.

Salah satu karakteristik belajar yang berkaitan dengan menyerap, mengolah, dan menyampaikan informasi tersebut adalah gaya belajar peserta didik. Gaya belajar merupakan modalitas belajar yang sangat penting. Sebagian peserta didik bisa belajar dengan sangat baik hanya dengan cara melihat orang lain melakukannya. Mereka menyukai cara penyajian informasi yang runtut. Selama pelajaran, peserta didik tersebut suka menulis apa yang dikatakan pendidik/guru/dosen. Peserta didik Visual ini berbeda dengan peserta didik Auditori yang mengandalkan kemampuan untuk mendengar. Sedangkan peserta didik Kinestetik lebih suka belajar dengan cara terlibat langsung.

Grinder (1991) dalam Siberman, Melvin L (2014:28) menyatakan bahwa setiap 30 siswa, 22 diantaranya rata-rata dapat belajar dengan efektif selama gurunya menghadirkan kegiatan belajar yang berkombinasi antara visual, auditori, dan kinestetik. Namun sisanya sedemikian menyukai salah satu bentuk pengajaran dibanding dua lainnya, sehingga siswa tersebut harus berupaya keras untuk memahami pelajaran bila tidak ada kecermatan dalam menyajikan pelajaran sesuai dengan cara yang mereka sukai.

Jika seorang anak menangkap informasi/materi sesuai dengan gaya belajarnya, maka tidak akan ada pelajaran yang sulit. Menurut Barbara Prashning dalam Chatib (2014:171) bahwa penyerapan informasi bergantung pada cara orang mengusahakannya. Dengan memberikan instruksi kepada anak-anak, kita melalui kekuatan gaya belajarnya, akan terlihat suatu perubahan sikap yang cepat dan tingkat keberhasilan yang tinggi. Dengan demikian, dapat dikatakan bahwa karakteristik gaya belajar yang dimiliki peserta didik merupakan salah satu modalitas yang berpengaruh dalam 
pembelajaran, pemrosesan, dan komunikasinya. Hal yang serupa, bila mahasiswa tersebut mengetahui karakteristik gaya belajarnya sendiri maka mahasiswa akan lebih muda memotivasi dirinya dalam pembelajaran. Hal serupa juga diungkapkan (Chatib, 2014:171) bahwa Gaya belajar anak seperti pintu pembuka. Setiap butir informasi yang masuk lewat pintu terbuka lebar, akan memudahkan anak memahami informasi itu. Pada Puncak pemahaman, informasi itu akan masuk ke memori jangka panjang dan tak terlupakan seumur hidup.

Peneliti memandang betapa besar manfaat informasi terkait karakteristik gaya belajar mahasiswa. Dengan adanya informasi terkait karakteristik gaya belajar mahasiswa yang akan diajari, maka dosen diharapkan dapat meningkatkan kualitas pembelajarannya. Dengan demikian, judul penelitian ini adalah Analisis Karakteristik Gaya Belajar VAK (Visual, Auditorial, Kinestetik) Mahasiswa Pendidikan Informatika Angkatan 2014.

Tujuan dalam penelitian ini antara lain;

1. mendeskripsikan hasil analisis karakteristik gaya belajar VAK (Visual, Auditorial, Kinestetik) pada mahasiswa pendidikan informatika Angkatan 2014;

2. mendeskripsikan beberapa karakteristik pembelajaran yang sesuai dengan masing-masing gaya belajar VAK (Visual, Auditorial, Kinestetik).

Beberapa manfaat yang diperoleh adalah sebagai berikut;

a) Manfaat bagi dosen (pendidik)

Adanya informasi terkait karakteristik gaya belajar mahasiswanya (terutama di awal pembelajaran) sangatlah bermanfaat dalam merancang satu pembelajaran sedemikian hingga sesuai dengan gaya belajar mahasiswa. Hal ini dilakukan untuk mempermudah dosen/pendidik dalam memahamkan peserta didik terkait materi/informasi yang diberikan. Hal serupa dikatakan dalam bukunya Chatib, Munif (2014:100) bahwa jika strategi mengajar guru sama dengan gaya belajar siswa, maka tidak ada pelajaran yang sulit.

b) Bagi mahasiswa (peserta didik)

Jika mahasiswa mengetahui karakteristik gaya belajar dirinya, maka mahasiswa akan dengan mudah mempelajari dan menyerap informasi sesuai dengan gaya belajar mereka.

\section{METODE PENELITIAN}

Penelitian ini merupakan penelitian non-eksperimen, yaitu tergolong pada penelitian deskriptif kualitatif Subjek penelitian ini adalah seluruh mahasiswa program studi pendidikan informatika yang berasal dari angkatan 2014, yang saat ini menduduki semester 1 tahun akademik 2014/2015. Dengan demikian, ditinjau dari subjek penelitian maka penelitian ini merupakan penelitian populasi.

Instrumen yang digunakan dalam penelitian ini berupa angket/kuesioner yang akan diisi oleh subjek penelitian. Angket/kuesioner berisi sejumlah pertanyaan tertulis yang digunakan untuk memperoleh informasi dari subjek penelitian terkait beberapa karakteristik gaya belajarnya. Instrumen angket/kuesioner tidak diuji coba namun hanya divalidasi oleh ahli bahasa untuk menghindarkan adanya ambigu atau 
pemaknaan ganda terhadap pertanyaan di dalamnya.

Ditinjau dari cara menjawabnya, angket/kuesioner yang digunakan termasuk dalam kuesioner tertutup, Karen subjek penelitian telah disediakan jawabannya. Ditinjau dari jawabannya, kuesioner yang digunakan dalam penelitian ini merupakan kuesioner langsung karena subjek penelitian langsung menjawab tentang dirinya. Sedangkan teknik/metode yang digunakan dalam pengambilan data penelitian ini adalah teknik angket/kuesioner.

Data angket yang diperoleh dari setiap responden akan dibuat rekapitulasinya berdasarkan masingmasing gaya belajar. Berikut ini beberapa langkah dalam analisis data tersebut:

1. Terdapat beberapa pertanyaan dalam instrumen angket yang akan diisi oleh respon. Terdapat 3 kelompok pertanyaan yang mencerminkan masing-masing gaya belajar, yaitu kelompok gaya belajar "V" (Visual), kelompok gaya belajar "A" (Auditorial), dan kelompok gaya belajar "K" (kinestetik) . Setiap pertanyaan memiliki jawaban pilihan yaitu: "sering" diberi skor 2, "kadangkadang" diberi skor 1, dan "jarang" diberi skor 0 .

2. Dari masing-masing kelompok pertanyaan gaya belajar, skor tersebut dijumlah sehingga pada tiap-tiap kelompok pertanyaan gaya belajar akan menghasilkan suatu nilai tertentu.

3. Penarikan kesimpulan kecenderungan gaya belajarnya dengan cara membandingkan tiga nilai masingmasing kelompok pertanyaan yang diisi oleh subjek tersebut. Penarikan kesimpulan didasarkan pada:

a) Jika terdapat nilai tertinggi pada suatu kelompok pertanyaan gaya belajar, maka disimpulkan subjek tersebut cenderung dominan pada gaya belajar tersebut;

b) Jika terdapat dua nilai tertinggi yang sama dari dua kelompok pertanyaan gaya belajar, maka subjek tersebut tergolong pada pada "Gabungan kedua Gaya Belajar" tersebut.

c) Jika terdapat dua nilai tertinggi dari dua kelompok pertanyaan gaya belajar yang berselisih 1 poin, maka subjek tersebut tergolong pada pada "Gabungan kedua Gaya Belajar" tersebut.

4. Setelah itu, akan dibuat rekapitulasi berupa:

a) persentase kecenderungan gaya belajar dari masing-masing kelas mahasiswa prodi pendidikan informatika angkatan 2014;

b) persentase kecenderungan gaya belajar secara keseluruhan dari mahasiswa angkatan 2014.

\section{HASIL DAN PEMBAHASAN}

Setelah dilakukan pengisian instrument angket gaya belajar oleh sebanyak 115 subjek penelitian yang berasal dari mahasiswa Pendidikan Informatika Angkatan 2014, kemudian dilakukan analisis/penghitungan skor tiap subjek penelitian.

Dalam penarikan kesimpulan suatu subjek cenderung pada suatu gaya belajar, penelitian ini menentukan 6 kelompok kecenderungan gaya belajar yaitu:

1. Visual (disimbolkan "V"), 
2. Auditorial (disimbolkan "A"),

3. Kinestetik (disimbolkan "K"),

4. Gabungan Visual dan Auditorial (disimbolkan "VA"),

5. Gabungan Visual dan Kinestetik (disimbolkan "VK"),

6. Gabungan Auditorial dan Kinestetik (disimbolkan "AK”).

\section{Kecenderungan Gaya Belajar tiap kelas pada mahasiswa Pendidikan Informatika Angkatan 2014}

Hasil analisis gaya belajar terhadap Mahasiswa Kelas A Angkatan 2014 di Prodi Pendidikan Informatika menghasilkan sebanyak 53\% Visual, 7\% Auditorial, $\quad 10 \% \quad$ Kinestetik, $23 \%$ Gabungan Visual dan Auditorial, 3\% \& Gabungan Visual dan Kinestetik, dan 3\% Gabungan Auditorial dan Kinestetik. Dengan demikian, dominasi kecenderungan Gaya Belajar Mahasiswa Kelas A adalah gaya belajar Visual. Data lengkap Gaya belajar Kelas A disajikan dalam Tabel 1 dan Gambar 1.

Tabel 1. Kecenderungan gaya belajar kelas A angkatan 2014 pendidikan informatika

\begin{tabular}{|c|c|c|c|}
\hline No & Gaya Be lajar & Frekuensi & $\mathbf{P}$ \\
\hline 1 & $\mathrm{~V}$ & 16 & $53 \%$ \\
\hline 2 & $\mathrm{~A}$ & 2 & $7 \%$ \\
\hline 3 & $\mathrm{~K}$ & 3 & $10 \%$ \\
\hline 4 & $\mathrm{VA}$ & 7 & $23 \%$ \\
\hline 5 & VK & 1 & $3 \%$ \\
\hline \multirow[t]{2}{*}{6} & $\mathrm{AK}$ & 1 & $3 \%$ \\
\hline & Total & 30 & $100,0 \%$ \\
\hline
\end{tabular}

$\mathrm{P}$ : Persentase

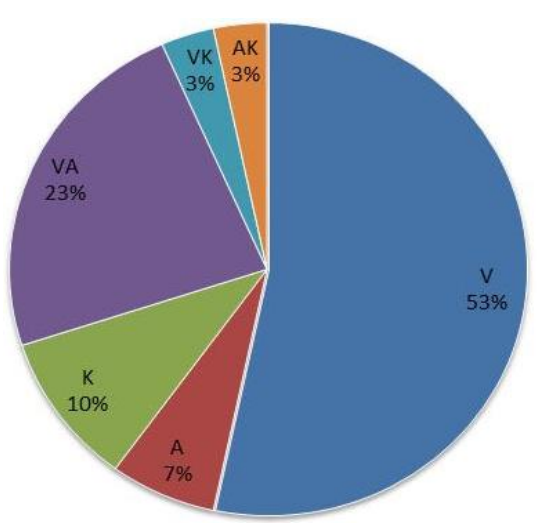

Gambar 1. Diagram persentase

kecenderungan gaya belajar kelasA angkatan 2014 pendidikan informatika

Hasil analisis gaya belajar terhadap Mahasiswa Kelas B Angkatan 2014 di Prodi Pendidikan Informatika menghasilkan sebanyak 23\% Visual, 35\% Auditorial, 5\% Kinestetik, 14\% Gabungan Visual dan Auditorial, 12\% Gabungan Visual dan Kinestetik, dan 12\% Gabungan Auditorial dan Kinestetik. Dengan demikian, dominasi kecenderungan Gaya Belajar Mahasiswa Kelas B adalah gaya belajar Auditorial. Data lengkap identifikasi Gaya belajar Kelas B disajikan dalam Tabel 2 dan Gambar 2.

Sedangkan hasil analisis data kecenderungan gaya belajar Mahasiswa Kelas C Angkatan 2014 Prodi Pendidikan Informatika menghasilkan sebanyak 29\% Visual, 19\% Auditorial, 10\% Kinestetik, 7\% Gabungan Visual danAuditorial, 12\% Gabungan Visual dan Kinestetik, dan 24\% Gabungan Auditorial dan Kinestetik. 
Tabel 2. Kecenderungan gaya belajar kelas B angkatan 2014 pendidikan informatika

\begin{tabular}{cccc}
\hline No. & Gaya Belajar & Frekuensi & P \\
\hline 1 & V & 10 & $23 \%$ \\
\hline 2 & A & 15 & $35 \%$ \\
\hline 3 & K & 2 & $5 \%$ \\
\hline 4 & VA & 6 & $14 \%$ \\
\hline 5 & VK & 5 & $12 \%$ \\
\hline 6 & AK & 5 & $12 \%$ \\
\hline \multicolumn{5}{c}{ Total } & 43 & $100 \%$ \\
\hline P : Persentase & &
\end{tabular}

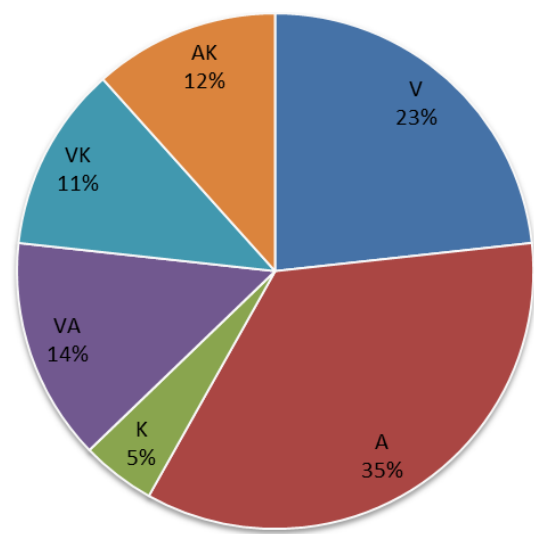

Gambar 2. Diagram persentase

kecenderungan gaya belajar kelas

Bangkatan 2014 pendidikan informatika

Dengan demikian, dominasi kecenderungan Gaya Belajar Mahasiswa Kelas $\mathrm{C}$ adalah gaya belajar Visual. Data lengkap identifikasi Gaya belajar Kelas C disajikan dalam Tabel 3 dan Gambar 3 berikut ini.

Tabel 3. Kecenderungan gaya belajar kelas $\mathrm{C}$ angkatan 2014 pendidikan informatika

\begin{tabular}{cccc}
\hline \multicolumn{2}{l}{ No. Gaya Belajar Fre kuensi } & P \\
\hline 1 & $\mathrm{~V}$ & 12 & $29 \%$ \\
\hline 2 & $\mathrm{~A}$ & 8 & $19 \%$ \\
\hline 3 & $\mathrm{~K}$ & 4 & $10 \%$ \\
\hline 4 & $\mathrm{VA}$ & 3 & $7 \%$ \\
\hline 5 & $\mathrm{VK}$ & 5 & $12 \%$ \\
\hline 6 & $\mathrm{AK}$ & 10 & $24 \%$ \\
\hline & Total & 42 & $100 \%$ \\
\hline
\end{tabular}

$\mathrm{P}:$ Persentase

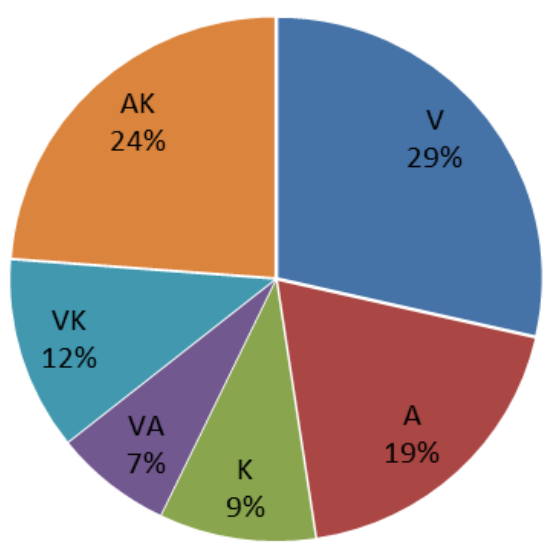

Gambar 3. Diagram persentase kecenderungan gaya belajar kelas $\mathrm{C}$ angkatan 2014 pendidikan informatika

\section{Kecenderungan Gaya Belajar secara umum pada mahasiswa Pendidikan Informatika Angkatan 2014}

Analisis terhadap kecenderungan gaya belajar keseluruhan mahasiswa Angkatan 2014 Prodi Pendidikan Informatika dilakukan dengan cara menjumlah seluruh frekuensi siswa dari tiap-tiap kelas dengan kecenderungan gaya belajar yang setara. Dengan demikian diperoleh hasil bahwa sebanyak 33\% Visual, 22\% Auditorial, 8\% Kinestetik, 14\% Gabungan Visual dan Auditorial, $10 \%$ Gabungan Visual dan Kinestetik, dan 14\% Gabungan Auditorial dan Kinestetik. Rincian analisis data terhadap kecenderungan gaya belajar Mahasiswa Prodi Pendidikan Pendidikan Informatika Angkatan 2014 disajikan padaTabel 4 dan Gambar 4 berikut ini, 
Tabel 4. Kecenderungan gaya belajar kelas mahasiswa angkatan 2014 prodi pendidikan informatika

\begin{tabular}{ccccccc}
\hline No & $\begin{array}{c}\text { Gaya } \\
\text { Belajar }\end{array}$ & $\mathbf{f ( a )}$ & $\mathbf{f ( b )}$ & $\mathbf{f ( c )}$ & $\mathbf{F i}$ & $\%$ \\
\hline 1 & $\mathrm{~V}$ & 16 & 10 & 12 & 38 & $33 \%$ \\
\hline 2 & $\mathrm{~A}$ & 2 & 15 & 8 & 25 & $22 \%$ \\
\hline 3 & $\mathrm{~K}$ & 3 & 2 & 4 & 9 & $8 \%$ \\
\hline 4 & $\mathrm{VA}$ & 7 & 6 & 3 & 16 & $14 \%$ \\
\hline 5 & $\mathrm{VK}$ & 1 & 5 & 5 & 11 & $10 \%$ \\
\hline 6 & $\mathrm{AK}$ & 1 & 5 & 10 & 16 & $14 \%$ \\
\hline & Total & 30 & 43 & 42 & 115 & $100 \%$ \\
\hline
\end{tabular}

KeteranganTabel 4.

$\mathrm{f}(\mathrm{a})$ : frekuensi masing-masing tipe gaya belajar kelas A

$\mathrm{f}(\mathrm{b})$ : frekuensi masing-masing tipe gaya belajar kelas B

$\mathrm{f}(\mathrm{c})$ : frekuensi masing-masing tipe gaya belajar kelas C

$\mathrm{Fi}$ : total frekuensi masing-masing gaya belajar

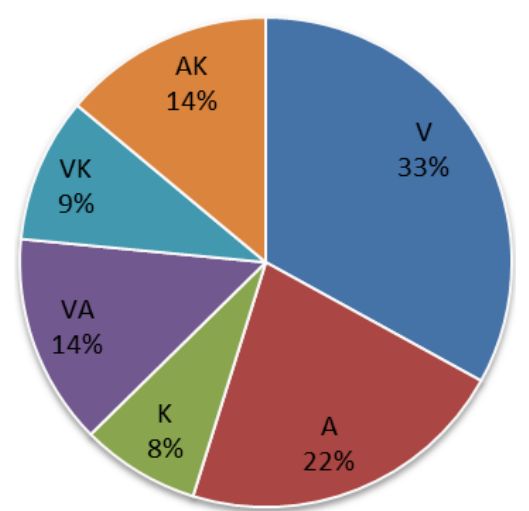

Gambar 4. Diagram persentase

kecenderungan gaya belajar mahasiswa angkatan 2014 prodi pendidikan informatika

Dengan demikian secara keseluruhan, kecenderungan gaya belajar Mahasiswa Angkatan 2014 Prodi Pendidikan Informatika didominasi oleh tipe gaya belajar Visual sebesar 33\%.

\section{Karakteristik Pembelajaran VAK (Visual-Auditorial-Kinestetik)}

Untuk menjawab pertanyaan penelitian yang ke-2, metode yang digunakan adalah mengkaji beberapa referensi sesuai dengan karakteristik masing-masing gaya belajar. Berikut ini disajikan beberapa karateristik Pembelajaran yang sebaiknya digunakan terhadap mahasiswa dengan kecenderungan gaya belajar Visual, Auditorial, ataupun Kinestetik.

\section{Pembelajaran untuk Mahasiswa Visual}

Mahasiswa yang sangat visual memiliki beberapa ciri sebagai berikut (Deporter,2014:123):

- Teratur, memperhatikan segala sesuatu, menjaga penampilan;

- Mengingat dengan gambar, lebih suka membaca daripada dibacakan; dan

- Membutuhkan gambaran dan tujuan menyeluruh.

Dengan demikian, maka beberapa karakteristik pembelajaran yang sesuai untuk mahasiswa yang sangat visual adalah sebagai berikut:

a) dosen berdiri tenang saat menyajikan segmen informasi, dan bergeraklah perlahan di antara segmen tersebut;

b) beri dorongan pada mahasiswa untuk menggambarkan informasi, dengan membuat diagram, simbol dan gambar berwarna dalam catatan mahasiswa Visual;

c) adanya Tabel dan Grafik akan memperdalam pemahaman mahasiswa Visual terutama dalam matematika, teknik, atau IPA;

d) adanya pembuatan Peta pikiran/ peta konsep akan sangat membantu 
mahasiswa Visual dalam memberikan "gambaran keseluruhan" suatu konsep;

e) gunakan bahasa simbol visual dalam presentasi dosen yang mewakili konsep kunci;

f) membiasakan mahasiswa untuk mencatat kembali materi/informasi dengan menggunakan aneka warna/gambar yang menarik;

g) perhatikan penerangan atau pencahayaan ruang saat belajar/pembelajaran berlangsung.

h) gunakan media pembelajaran berupa Buku, majalah, Poster, Komputer/LCD, Kolase, Flow chart, Highlighting, kata kunci yang dipajang di sekeliling kelas, tulisan dengan warna menarik.

\section{Pembelajaran untuk Mahasiswa Auditorial}

Mahasiswa yang sangat auditorial memiliki beberapa ciri sebagai berikut (Deporter,2014:124):

- perhatiannya mudah terpecah;

- berbicara dengan pola berirama;

- belajar dengan cara mendengarkan, menggerakkan bibir/bersuara saat membaca;

- berdialog secara internal dan eksternal.

Sesuai dengan ciri mahasiswa auditorial tersebut, berikut ini beberapa karakteristik pembelajaran yang sesuai:

a) berikan informasi secara berulangulang, dapat memanfaatkan metode tanya jawab;

b) gunakan teknik pengulangan, minta mahasiswa untuk menyebutkan kembali konsep dan petunjuk;

c) dosen menggunakan variasi vokal dalam presentasi; d) nyanyikan konsep kunci atau mintalah mahasiswa untuk membuat lagu terkait konsep tersebut;

e) beri dorongan pada mahasiswa untuk membuat/memikirkan "jembatan keledai" untuk mempermudah menghafalkan/ mengingat konsep kunci;

f) gunakan teknik tanya jawab;

g) menggunakan metode tanya jawab, bermain peran, kerja kelompok, teknik mnemonics;

h) melibatkan musik dalam pembelajaran.

\section{Pembelajaran untuk Mahasiswa Kinestetik}

Gerakan, koordinasi, irama, tanggapan emosional, dan kenyamanan fisik sangat menonjol pada mahasiswa yang sangat kinesterik. Sesuai dengan yang diungkapkan dalam Deporter dkk (2014:124) bahwa beberapa ciri seseorang yang kinestetik antara lain:

- sering menyentuh orang, berdiri berdekatan, dan bergerak saat berinteraksi dengan orang lain;

- belajar dengan melakukan;

- menunjuk tulisan saat membaca;

- mengingat sambil berjalan dan melihat.

Oleh karena itu, berikut ini beberapa karakteristik pembelajaran yang sesuai dengan mahasiswa yang sangat kinestetik, antara lain:

a) mahasiswa kinestetik lebih menyukai tugas berupa proyek terapan;

b) gunakan media pembelajaran/ alat bantu saat mengajar untuk menimbulkan rasa ingin tahu dan menekankan konsep kunci;

c) ijinkan mahasiswa kinestetik untuk berjalan-jalan di kelas; 
d) peragakan konsep sambil memberikan kesempatan kepada mahasiswa untuk mempelajarinya langkah demi langkah;

e) ciptakan simulasi konsep agar mahasiswa mengalaminya;

f) membuat peta pikiran dengan melibatkan aktivitas fisik juga dapat bermanfaat bagi mahasiswa kinestetik.

Berdasarkan hasil penelitian di atas, terdapat pula beberapa mahasiswa yang memiliki kecenderungan gabungan beberapa gaya belajar, maka sebaiknya dosen diharapkan mampu menciptakan pembelajaran yang menggabungkan beberapa karakteristik gaya belajar tersebut.

\section{KESIMPULAN DAN SARAN}

Berdasarkan tujuan penelitian dan hasil beserta pembahasan diperoleh beberapa kesimpulan sebagai berikut:

a) gaya belajar mahasiswa kelas A Angkatan 2014 Prodi Pendidikan Informatika didominasi olehgaya belajar Visual sebanyak 53\% dari total mahasiswa di kelas A;

b) gaya belajar mahasiswa kelas B Angkatan 2014 Prodi Pendidikan Informatika didominasi oleh gaya belajar Auditorial sebanyak 35\% dari total mahasiswa di kelas B;

c) gaya belajar mahasiswa kelas C Angkatan 2014 Prodi Pendidikan Informatika didominasi oleh gaya belajar Visual sebanyak 29\% dari total mahasiswa di kelas C;

d) gaya belajar mahasiswa Angkatan 2014 Prodi Pendidikan Informatika didominasi oleh gaya belajar Visual sebanyak $33 \%$ dari total seluruh mahasiswa.
Adapun beberapa saran penelitian ini antara lain:

a) untuk mencapai hasil belajar yang maksimal, diharapkan dosen dapat menciptakan pembelajaran yang mampu melibatkan banyak gaya belajar secara bersamaan;

b) setelah mengetahui kecenderungan gaya belajarnya, masing-masing mahasiswa diharapkan mampu memanfaatkan gaya belajarnya dalam mempelajari/ memahami informasi.

\section{DAFTAR PUSTAKA}

Arikunto, suharsimi. 2002. Prosedur Penelitian Suatu Pendekatan Praktek. Jakarta: PT Rineka Cipta.

Chatib, munif. 2014. Orangtuanya Manusia: Melejitkan Potensi dan Kecerdasan dengan Menghargai Fitrah Setiap Anak. Bandung: PT Mizan Pustaka.

Chomaria, Nurul. 2014. Tes Kepribadian Remaja Muslim. Surakarta: AlQudwah Publishing.

DePorter, Bobbi., Mark Reardon,\&Sarah Singer-Nourie. 2014. Quantum Teaching. Bandung: PT Mizan Pustaka.

Gunawan, Adi W. 2012. Born to be a Genius. Jakarta: PT Gramedia Pustaka Utama.

Gunawan, Adi W. 2012. Genius Learning Strategy. Jakarta: PT Gramedia Pustaka Utama. 
Kosasih, N. \& Dede Sumarna. 2013. Pembelajaran Quantum dan Optimalisasi Kecerdasan. Bandung: Alfabeta.

Novita Sari, Ade Rakhman. 2014. How Great is Your Personality?. Yogyakarta: Cemerlang Publishing.

Rufiana, Intan Sari. 2013. Analisis Karakteristik Gaya Belajar Mahasiswa Jurusan Pendidikan Matematika ditinjau dari Preferensi Sensori, diunduh dari http://lib.umpo.ac.id/gdl/files/disk1/8 /jkptumpo-gdl-intansarir-357-1analisis-n.pdf. Diakses tanggal 31 Oktober 2014.

Siberman, Melvin L. 2014. Active Learning; 101 cara Belajar Siswa Aktif. Bandung: Nuansa Cendekia. 
